Short communication

\title{
The Cretaceous crocodyliform Caipirasuchus: behavioral feeding mechanisms
}

\author{
Fabiano Vidoi Iori ${ }^{\mathrm{a}, \mathrm{b}}{ }^{*}$, Ismar de Souza Carvalho ${ }^{\mathrm{c}}$ \\ a Museu de Paleontologia "Prof. Antonio Celso de Arruda Campos", Centro de Artes, Praça do Centenário, 15910-000, Monte Alto, SP, Brazil \\ b Museu de Paleontologia "Pedro Candolo", Estação Cultura, Praça Farmacêutico Bruno Garisto, 15890-000, Uchoa, SP, Brazil \\ ' Universidade Federal do Rio de Janeiro, Instituto de Geociências, Departamento de Geologia, Cidade Universitária, Ilha do Fundão, Av. Athos da Silveira \\ Ramos, 274, 21941-916, Rio de Janeiro, RJ, Brazil
}

\section{A R T I C L E I N F O}

\section{Article history:}

Received 6 June 2017

Received in revised form

12 November 2017

Accepted in revised form 24 November 2017

Available online 2 December 2017

\section{Keywords:}

Caipirasuchus

Sphagesauridae

Mastication processes

\begin{abstract}
A B S T R A C T
Caipirasuchus is a sphagesaurid crocodyliform from the Cretaceous of the Bauru Basin. Three species, with terrestrial habits, leaned bodies and measuring less than $1.5 \mathrm{~m}$ in length, have been described up to now: Caipirasuchus montealtensis, $C$. paulistanus and $C$. stenognathus. Similar to other advanced notosuchians, they present a complex mastication mechanism that includes propalinal movements, side alternation during chewing and tooth-to-tooth occlusion. This study analyzes the anatomic structures and dental wear related to such mastication mechanisms in Caipirasuchus, in corresponding to feeding strategies.
\end{abstract}

(C) 2017 Elsevier Ltd. All rights reserved.

\section{Introduction}

Notosuchia was one of the most peculiar groups during the Cretaceous of Gondwana. These crocodyliforms were essentially terrestrial and had very specialized dentition, indicating that had occupied various ecological niches (Carvalho and Bertini, 1999). Among these crocodyliforms is Sphagesauridae, mainly characterized by presenting a set of teeth adapted to herbivory/omnivory and a complex mastication mechanism (Pol, 2003; Marinho and Carvalho, 2009; Novas et al., 2009; Iori and Carvalho, 2011; Iori et al., 2011; Kellner et al., 2011a). The diagnoses of this clade were initially based on two isolated posterior teeth, that differ strongly from the dentition of other reptiles (Price, 1950; Kuhn, 1968).

In the Bauru Basin, São Paulo state, Brazil, five genera attributed to sphagesaurids were discovered: Sphagesaurus, Adamantinasuchus, Armadillosuchus, Caipirasuchus and Caryonosuchus (Pol, 2003; Nobre and Carvalho, 2006; Andrade and Bertini, 2008; Marinho and Carvalho, 2009; Iori and Carvalho, 2011; Kellner et al., 2011a; Iori et al., 2013; Pol et al., 2014). This basin (Fig. 1) is a broad cratonic depression developed during the Late Cretaceous in the southeastern portion of the South American Plate (Fernandes and Coimbra, 1996) between the Coniacian and Maastrichtian (Fernandes and Coimbra, 2000). Dias-Brito et al. (2001) suggested two sedimentary episodes: one in the Turonian-Santonian interval (represented by the Adamantina, Araçatuba and São José do Rio Preto formations) and the other in the Maastrichtian (the Marília Formation). Menegazzo et al. (2016) suggested that the history of the basin spans from the Cenomanian to the early Paleocene.

Caipirasuchus was a genus widely distributed in the Bauru Basin, and the three know species, Caipirasuchus montealtensis, C. paulistanus and C. stenognathus, have been recovered from sandstones of the Adamantina Formation (Upper Cretaceous), deposited in different environmental contexts. In the deposits of the Monte Alto region, the crocodyliform specimens are commonly found in paleosols, whereas the Catanduva specimens come from flooded plains (Iori et al., 2013).

We have analyzed here the morphological features and tooth wear observed in Caipirasuchus. The new observation has contributed to enhance our knowledge on the mastication mechanism in Caipirasuchus and enabled a greater understanding of its paleoautoecology.

\footnotetext{
* Corresponding author.

E-mail addresses: biano.iori@gmail.com (F.V. Iori), ismar@geologia.ufrj.br (I.S. Carvalho).
} 


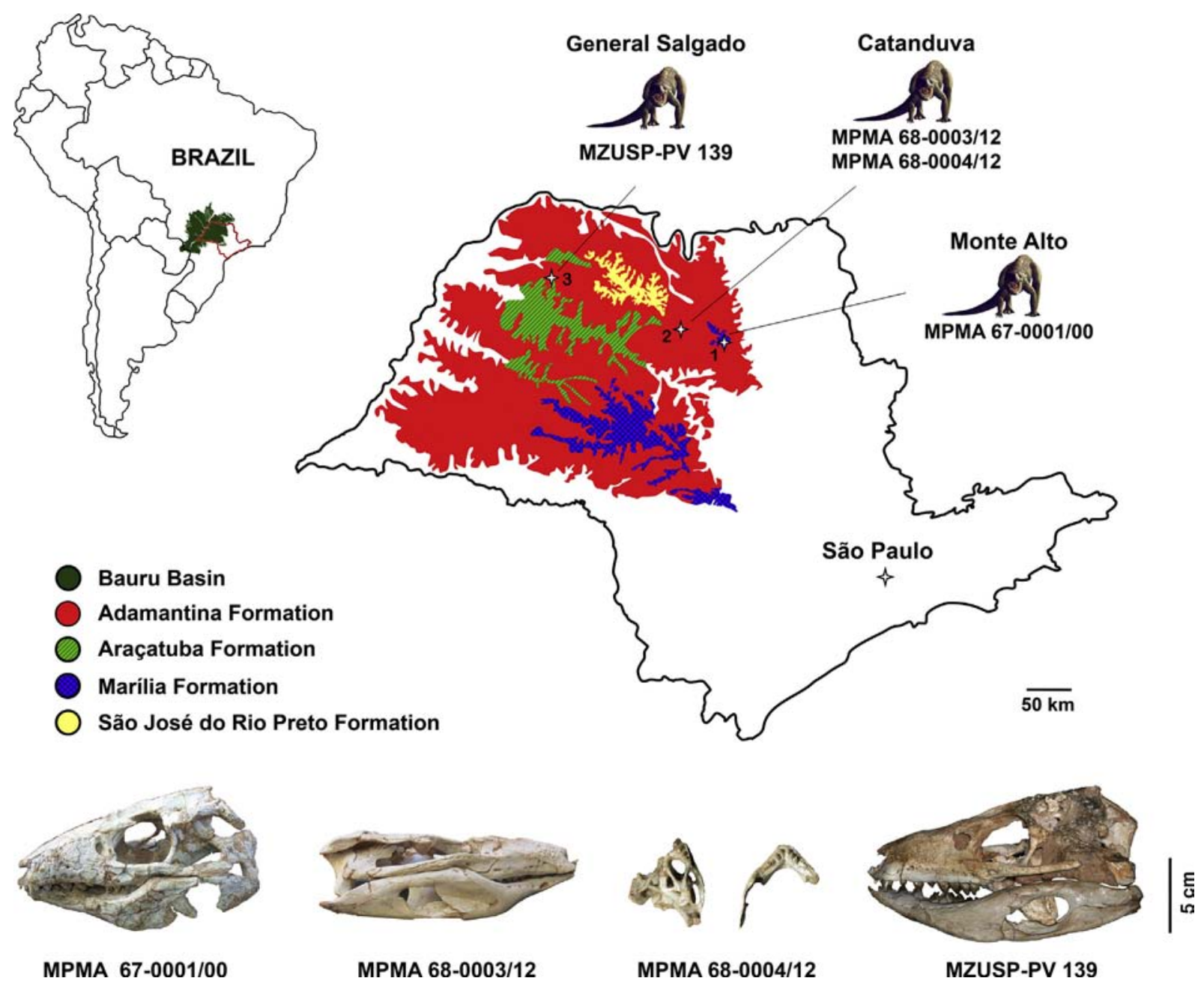

Fig. 1. Caipirasuchus crocodyliforms analyzed from the Bauru Basin and their geographical distribution.

\section{Materials}

\subsection{Specimens of Caipirasuchus}

Cranial elements related to the mastication mechanisms of four specimens of Caipirasuchus (Fig. 1), all coming from the sandstones of the Adamantina Formation (Bauru Group, Bauru Basin), were here studied (see Fig. 1). Specimen MPMA 67-0001/00 is the holotype of Caipirasuchus paulistanus and was found in Monte Alto. The specimens of $C$. montealtensis are MPMA 68-0003/12 (an adult) and MPMA 68-0004/12 (a youth) were from Catanduva. The holotype of C. stenognathus (MZSP-PV 139) is from General Salgado.

\subsection{Institutional abbreviations}

MPMA, Museu de Paleontologia "Prof. Antonio Celso de Arruda Campos”, Monte Alto, SP, Brazil; MZSP-PV, Museu de Zoologia, Universidade de São Paulo, São Paulo, Brazil.

\subsection{Anatomical abbreviations}

amf, anterior surface of retroarticular medial flange; an, angular; art, articular; aw, apical wear; c, crown; d, dentary tooth; dent, dentary; gc, gleinoid crest; lcq, lateral condyle of the quadrate; lw, lingual wear; $\mathbf{m}$, maxillary tooth; mcq, medial condyle of the quadrate; pm, premaxillary tooth; pt, pterygoid; q, quadrate; r, root; rap, retroarticular process; rlf, retroarticular lateral flange; rdg, ridges; sa, surangular; sp, splenial; sph, sphagesauriform tooth.

\section{Morphological features and mastication}

The description of a nearly full skull and the anterior part of the mandible of a specimen of Sphagesaurus huenei by Pol (2003) allowed the inference of relevant aspects of mastication in the species, such as tooth-by-tooth occlusion, propalinal movements and side alternation in mandible movements, as well as mechanisms that so far had not been noticed in crocodyliforms. The movements involved in mastication, inferred in Sphagesaurus huenei, have been found in other members of the family, such as Armadillosuchus, Caryonosuchus and Caipirasuchus (Marinho and Carvalho, 2009; Iori and Carvalho, 2011; Kellner et al., 2011a; Pol et al., 2014).

Iori and Carvalho (2011) simulated the bite of Caipirasuchus paulistanus in plasticine and found two areas of action: an anterior area of apprehension, and another for effective food processing in the posterior area.

In a detailed study on the mastication mechanisms of heterodontiform crocodylomorphs, Ösi (2013) corroborates previous studies on the mandibular movements of sphagesaurids and 
observes that, in this clade, propalinal movement is greater than in any other crocodyliforms.

The osteological analysis of the quatrate-articular joint, the dentition arrangement, diastemata and the relationships between lower and upper dentition of Caipirasuchus allowed the mastication process reconstruction and the inference of the possible eating habits of Caipirasuchus.

\subsection{Quadrate-articular joint}

Ösi (2013) points out the unusual medial hemicondyle of the quadrate bone observed in Caipirasuchus paulistanus (MPMA 67$0001 / 00$ ), which is very conspicuous and has an edge of about $1 \mathrm{~cm}$ ventral to the lateral hemicondyle. However, he stressed that no sphagesaurid had so far presented a fully preserved quadratearticular contact. A specimen of Caipirasuchus montealtensis (MPMA 68-0003/12) and the holotype of Caipirasuchus stenognathus preserve that region, and as in the C. paulistanus, the ventral surface extends further ventrally on the medial than on the lateral hemicondyle (Fig. 2) (Iori et al., 2013; Pol et al., 2014).

The articulars in the specimes of Caipirasuchus present similar aspects: they are wider than taller; they have a semi-circular medial contour; and the retroarticular processes are very small (Iori and Carvalho, 2011; Iori et al., 2013; Pol et al., 2014). The largest mediolateral axis of the bone is under an almost-flat surface in C. montealtensis, while in C. paulistanus there is a lower medial salience in contact with the quadrate's medial condyle. The dorsal surface of the articular is not preserved in

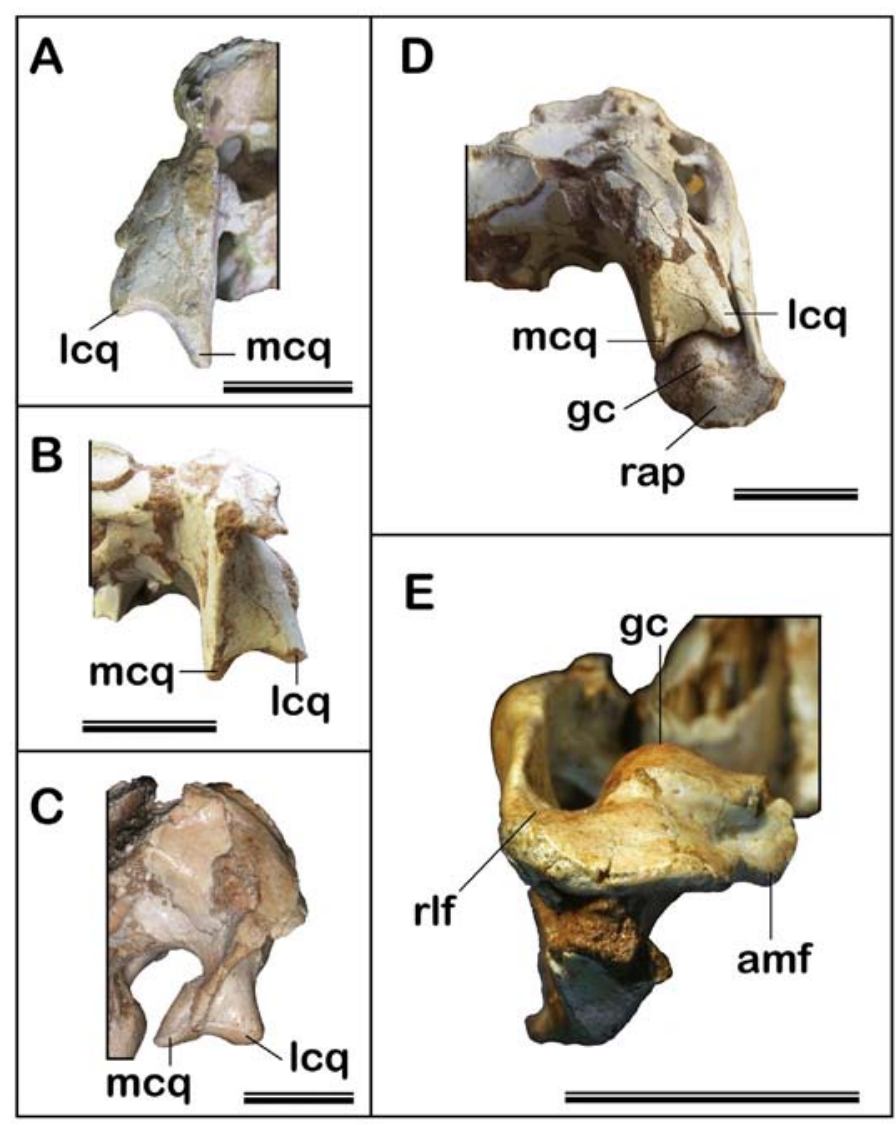

Fig. 2. Quadrates in posterior view in Caipirasuchus paulistanus (MPMA 67-0001-00) (A), C. montealtensis (MPMA 68-0003/12) (B) and C. stenognathus (MZSP-PV 139) (C). Articular-quadrate joint of the specimen MPMA 68-0003/12 (D) and articular of the C. stenognathus in posterior view (E). Scale bars $=25 \mathrm{~mm}$.
C. paulistanus, but in C. montealtensis (MPMA 68-0003/12) and C. stenognathus is almost intact (Figs. 2 and 3). Both lack the glenoid fossa typical of crocodyliforms (with a lateral-medial orientation and a crest separating it in two parts). The glenoid crest, an antero-posteriorly elongate intumescence, is bordered on its sides by a shallow fossa and medially by a small bone expansion. The glenoid crest fits between the quadrate condyles and is about twice as long as the quadrate region that is in contact with it (Figs. 2 and 3).

When in occlusion on the anteriormost position of the mandible (Fig. 3A), the quadrate articulates with the posterior half of the articular intumescence and the posterior margin of the quadrate condyles aligns to the beginning of the retroarticular process (Fig. 3A2 and A3). In this position, all mandibular teeth are externally bordered by the skull teeth. When the mandible is articulated in its furthest posterior position (Fig. 3B), the apices of the five last mandibular teeth are almost aligned to the anterolateral margin of the suborbital fenestra.

\subsection{Dentition arrangement}

The mandibular teeth in Caipirasuchus paulistanus and C. montealtensis are arranged into two straight lines. The 1 st through 6 th teeth are arranged in one line, parallel to the sagittal plane, another line begins at the 6 th tooth and diverges laterally by about $40^{\circ}$ from the sagittal plane, where it extends to the 10th tooth (Fig. 4B). The right and left teeth in the first sequence are very close and the apices of the symmetrical teeth are less than $1 \mathrm{~cm}$ apart. Symmetrical teeth in the second sequence start distancing themselves posteriorly and are arranged in a "V" shape. When the two sequences on both sides are combined, we have a "Y" shape arranged dentition (Fig. 4B).

The upper dentition presents a similar aspect to mandibular with regards to the posterior teeth. The sequences of the five last pairs of teeth are aligned into straight lines diverging about $40^{\circ}$ laterally forming a "V" shape (Fig. 4A). The line parallel to the sagittal axis encompasses the 4th pre-maxillary through the 2nd maxillary teeth. The pre-maxillary tooth row forms a parabolic arc, wherein the caniniform (3rd tooth) is mostly lateral, making this region of the snout slightly wider (Fig. 4A).

The gap between the right and left series of the upper dentition can easily fit the set of mandibular teeth (Fig. 4C), enabling propalinal movement without obstruction.

The holotype of Caipirasuchus stenognathus has a subtle plastic deformation and the lines of teeth implantation are not well defined.

\subsection{Diastemata}

A peculiar feature of Caipirasuchus is the presence of four pairs of diastemata. Each dentary has two: one between the 3rd and 4th teeth and another between the 4th and 5th teeth (Fig. 4B and C). One diastema is located between the 4th premaxillary and 1st maxillary teeth (Fig. 4A and C). Within each pre-maxillary set there is a diastema between the 3rd and 4th teeth (Fig. 4A and C). Other smaller spaces can be observed between the 3rd and 4th premaxillary teeth and the 1st and 2nd maxillary teeth (Fig. 4).

\subsection{Correlations between the upper and lower dentition}

\subsubsection{Antagonistic teeth}

The dentition of Caipirasuchus species shares, along with advanced notosuchians the presence of three main crown morphologies: incisiviform, caniniform, and molariform. 

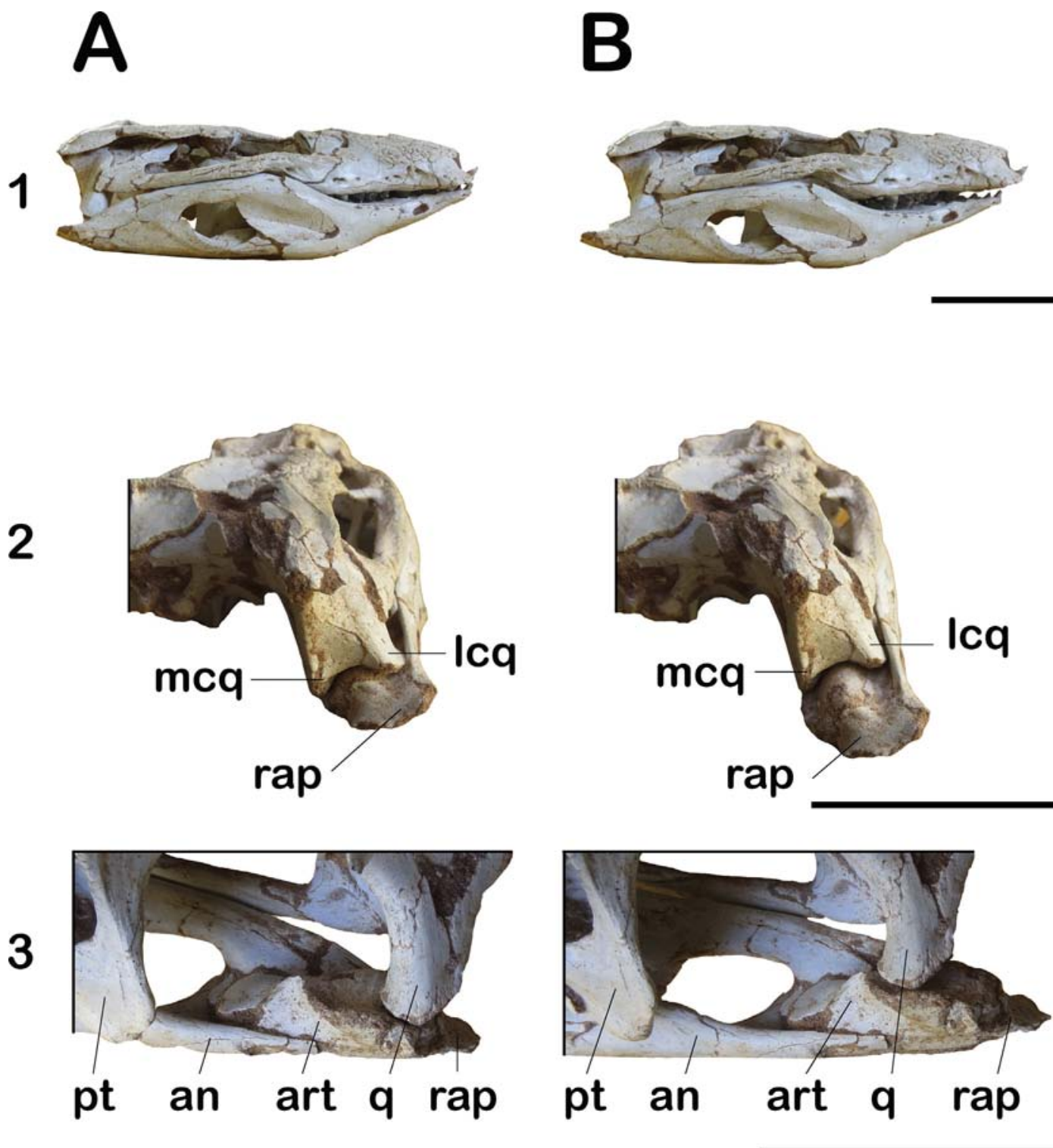

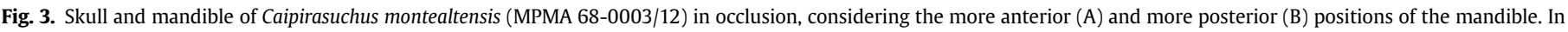
(1), right lateral view of the skull and mandible. In (2) and (3), joint between the right quadrate and articular, in posterior (2) and medial views (3). Scale bar $=50$ mm.

The posterior teeth in sphagesaurids are very peculiar with oblique implantation, a long root with an oval cross section and a triangular crown with a tubercular keel, here called "sphagesauriform". These teeth have their keels oriented posteromedially on the skull and anterolaterally on the mandible so that there is opposition between these keels (Fig. 4). The result of this contact is the wear of the enamel and the formation of wide surfaces of exposed dentin. The same oblique orientation of the keels does not occur on the 1st sphagesauriform tooth (d5) in the dentary and on the last maxillary tooth (m6), so the occlusion of these teeth is different from that of other posterior ones.

The keel on the second maxillary tooth $(\mathrm{m} 2)$ slides over the keel of the second sphagesauriform tooth of the dentary (d2). Considering the upper and lower sets of six sphagesauriform teeth, the standard of antagonistic keels occurs in the following contacts: $\mathrm{m} 2 \leftrightarrow \mathrm{d} 2, \mathrm{~m} 3 \leftrightarrow \mathrm{d} 3, \mathrm{~m} 4 \leftrightarrow \mathrm{d} 4$ and $\mathrm{m} 5 \leftrightarrow \mathrm{d} 5$. The first sphagesauriform tooth in the dentary (d1) presents its keel anteriorly and the contact with the keel on the first maxillary tooth (m1) occurs anterolaterally. The keel on the last maxillary tooth (m6) is medially oriented and contacts the side of the last mandibular tooth (d6) (Fig. 4C).

The specimen MPMA 68-0003/12 had its skull and mandible fossilized in occlusion. A relevant aspect that can be observed is the positioning of the apices of several of the sphagesauriform teeth. The first four sphagesauriform teeth in the mandibular series kept their apices in the medial-most portion of the maxillary cavities of their respective antagonistic teeth.

\subsubsection{Wear in the crown}

The sphagesauriform teeth of MPMA 68-0003/12 are quite worn, and in some the keel is completely gone (Fig. 5). In almost all wear facets is possible to observe the orientation of the grooves caused by jaw movements during feeding.

The mandibular sphagesauriform teeth present their worn faces turned to the side and almost on the same plan; their grooves are parallel, with inclinations on the posteroapical-anterobasal orientation of about 17th (Fig. 5). On the maxillary teeth, the wear facets are medially oriented and in the parallel grooves, the orientation, in 

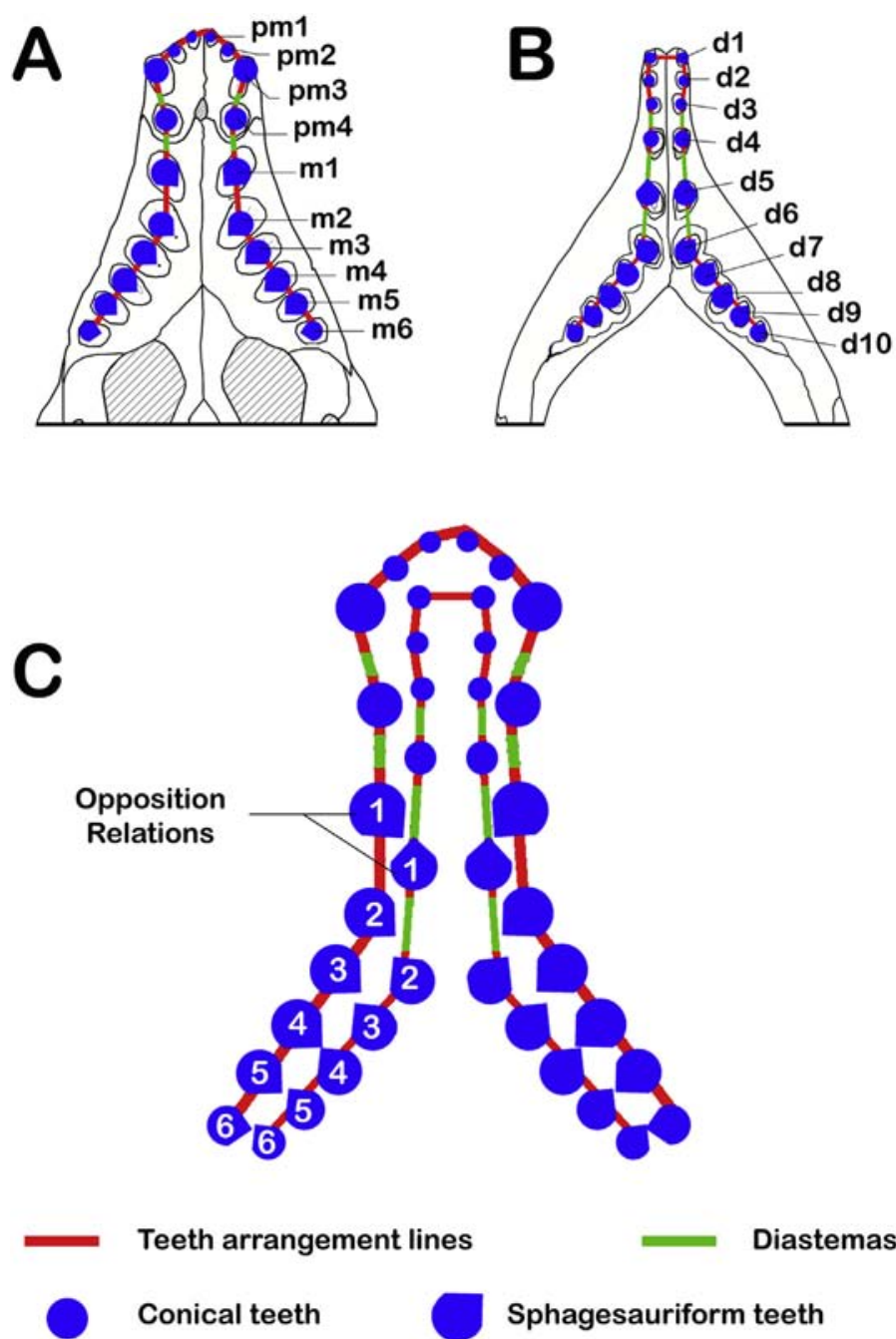

Teeth arrangement lines

Diastemas

\section{Conical teeth}

\section{Sphagesauriform teeth}

Fig. 4. Schematic drawing showing the arrangement and position of the teeth and diastemas in the upper (A) and lower dentition (B) of the Caipirasuchus. In (C), a scheme showing the arrangement and relation between the teeth and the cranial and mandibular diastemas during dental occlusion. this case, is anteroapical-posterobasal. The conical teeth of the mandible present apical wear; the hypertrophied tooth, in addition to apical wear, presents medial wear in the proximal half of the crown (Fig. 6).

In a young specimen (MPMA 68-0004/12) of Caipirasuchus montealtensis there are five preserved sphagesauriform teeth in the left dentary (Fig. 7), four in the right dentary and four in the right maxilla. They present the same oblique implantation patterns of the family. Anteromedial tooth decay can be observed on the keels of the skull teeth, and on mandibular teeth the wear occurs on the posterolateral face of the keels as in the adult specimens.

\section{Discussion}

The gondwanic crocodyliforms stand out for the great array of forms, and among these are the advanced notosuchians, a monophyletic group that includes Notosuchus, Llanosuchus, Mariliasuchus, Morrinhosuchus, Labidiosuchus and Sphagesauridae (Fiorelli et al., 2016). Pol et al. (2014) inferred for most species of the group feeding mechanisms that include: fore-aft movements of the lower, a lateral jaw movement and the presence of an alternate unilateral occlusion pattern.

The holotypes of Morrinhosuchus and Labidiosuchus are fragmentary, mastication mechanisms were not proposed for these taxa, however an omnivory feeding strategy was inferred for both based on the analysis of dental crowns (Iori and Carvalho, 2009; Kellner et al., 2011b). Based on the dental wear of the quadrate condyles, Zaher et al. (2006) suggested that Mariliasuchus had an anteroposterior movement of the lower jaws and a pattern of tooth-to-tooth occlusion.

Notosuchus shares with Sphagesauridae the presence of teardrop shaped dentition in cross section, with the major axis obliquely oriented, and the acute edge formed by an extensive sharp keel directed posteromedially in the upper toothrow and anterolaterally in the lower toothrow (Lecuona and Pol, 2008). In addition, the articular-quadrate joint is very similar to Caipirasuchus.

The chewing mechanisms hereof mentioned were also inferred for other Sphagesauridae, such as: Sphagesaurus, Armadillosuchus and Caryonosuchus, even for Caipirasuchus (Pol, 2003; Marinho and Carvalho, 2009; Iori \& Carvalho, 2011; Kellner et al., 2011a).
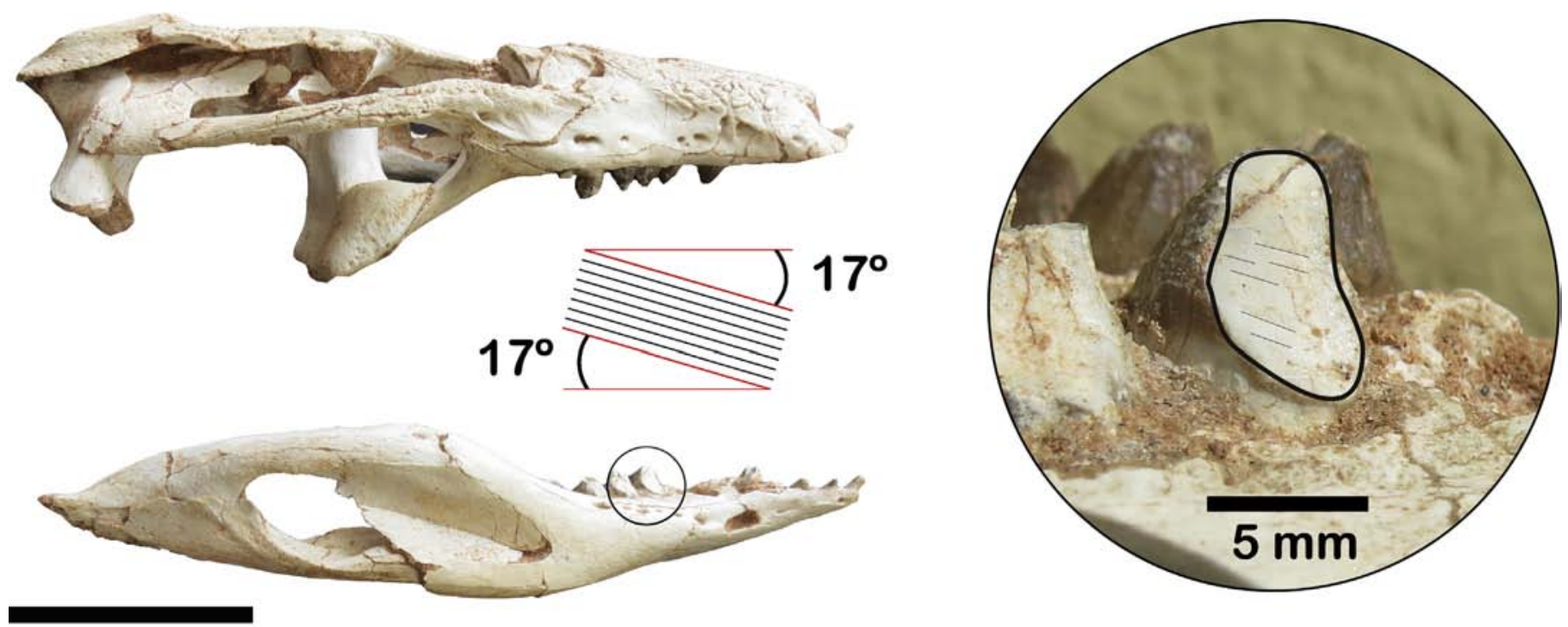

$50 \mathrm{~mm}$

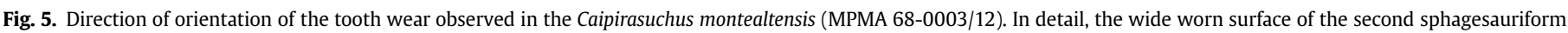
tooth in the mandible. 


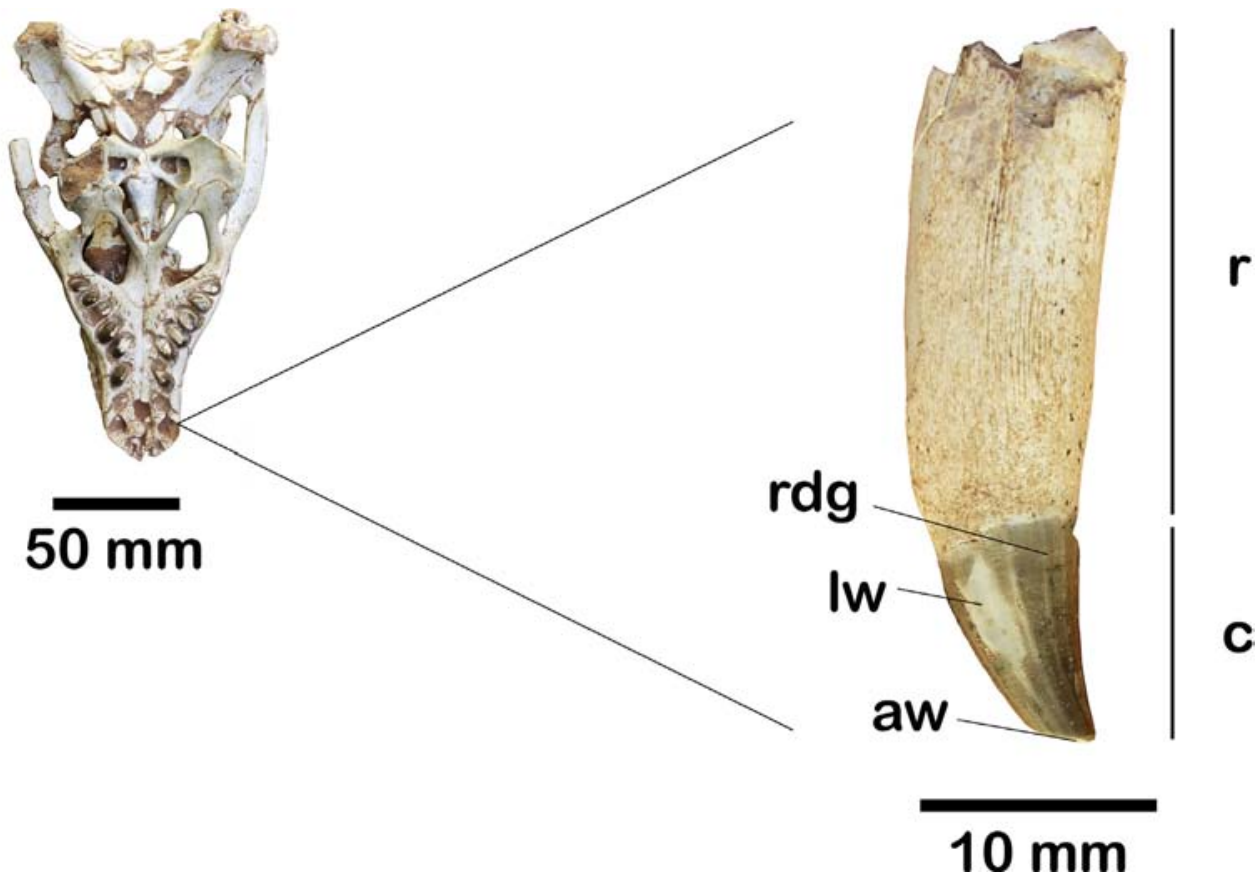

Fig. 6. Lingual view of the right caniniform tooth of Caipirasuchus montealtensis (MPMA 68-0003/12).

Certainly, such mechanisms occurred in all advanced notosuchians, but there was a variation in the extent of these movements among the different species. Iori \& Carvalho (2011) highlighted the peculiar elongated face of Caipirasuchus paulistanus and align the rostral development of the species with an advantage for food seizure. This advantage, however, is also related to the structural changes that allowed an increase of effectiveness in the movements of the mandible.

The features related to mastication observed in the analyzed fossils allow inference of the complex mechanisms involved in the bite of Caipirasuchus.
The hypothesis of a propalinal movement proposed by Pol (2003) for the Sphagesaurus huenei was based on the observation of wear on the first maxillary tooth opposed to the mandibular tooth and on the parallel orientation of these wear signs. In Caipirasuchus montealtensis (MPMA 68-0003/12), the following features support the existence of propalinal movement: the articular with a wide glenoid crest antero-posteriorly oriented, twice as long as the articular surface of the quadrate; and the grooves on the crowns of the sphagesauriform teeth.

In the model proposed by Ösi (2013) it is suggested that in Caipirasuchus, an anterior projection of the mandible occurred,

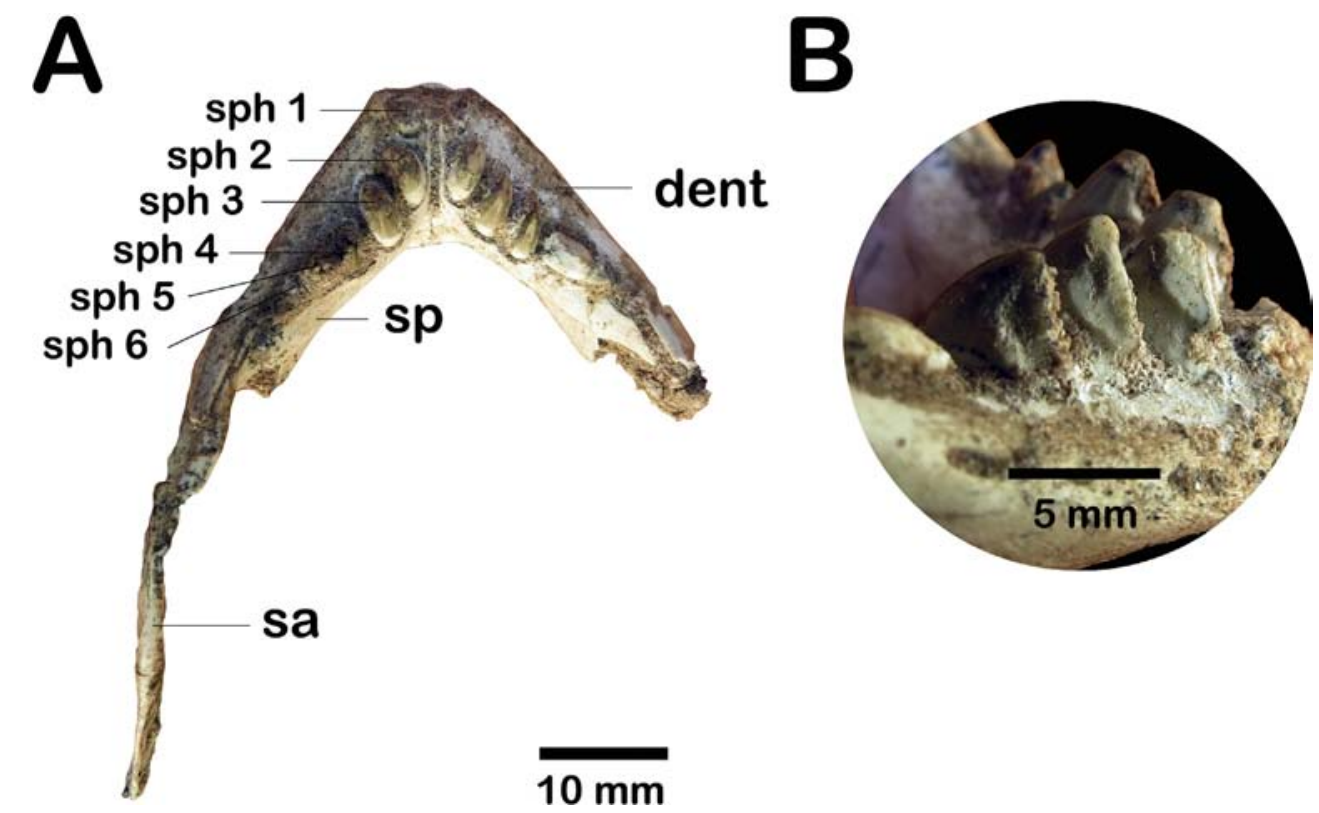

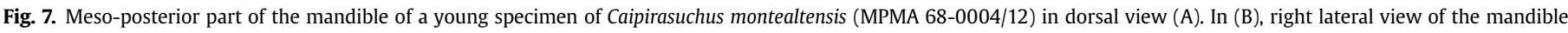
detailing the tooth decay in the $2-4$ sequence of sphagesauriform teeth. 
surpassing the anterior margin of the skull when the animal closed its mouth. However, the analysis of the skull-mandible occlusion based on the articular-quadrate joint shows that this projection would be impossible, as it would luxate the quadrate joint. On the most anterior position of the mandible, the more anterior mandibular teeth would be positioned right behind the first premaxillary teeth, and during the mastication process the mandible could only occupy a more posterior position, never anterior.

The proposal of a side alternation in mandible movement conceived by Pol (2003) based on fossil RCL-100 was based on the dimensions between the upper and lower dentition and the lack of contact occurring concurrently between teeth on the right and left sides. Such features have also been observed in Caipirasuchus.

The shallow angles observed in tooth wear would probably have occurred during mastication movements, when the mouth could not be too opened. Thus, it is suggested that there were two stages during the animal's feeding, one when the food was captured - with a simple open-close movement of the mouth, and another when the food was processed. The "Y" shaped mandible would enable propalinal movement to occur without obstruction. However, during mastication, with the lateral movement of the mandible, its more anterior region would suffer a greater dislocation. Its propalinal movement would be compromised if not for the existence of the diastemata that held the teeth and enabled the front and back movements. The wider region and the diastema of the pre-maxillary tooth fits the first three mandibular teeth, with the first of these probably causing attrition with the side of the hypertrophied caniniform, explaining the wear observed in these teeth. The diastema between the 4th premaxillary tooth and the 1st maxillary one would receive the 4th dentary tooth. The more anterior dentary diastema (between the 4th and 5th teeth) would accommodate the 4th premaxillary tooth, while the more posterior one (between the 5th and 6th teeth) would fit the 2 nd maxillary tooth.

As the keels became worn, wide surfaces would form on the crowns, and the attrition between the upper and lower teeth would stop exerting an effective cutting action and would act as a molar tooth, macerating the food.

\section{Conclusions}

The data surveyed to the bite of Caipirasuchus fossils supports previous proposals of propalinal movements and side alternation of the mandible during mastication in sphagesaurids. The anteroposterior displacement amplitude of the mandible during propalinal movements was wide; however, the mandible did not surpass the anterior limit of the skull. The presence of tooth wear on MPMA 68-0004/12 indicates that the elaborate mastication mechanism was also present on earlier ontogenetic stages. Moreover, the continuous shearing between sphagesauriform teeth caused the wear of the keels and an increase in contact area between opposing teeth, giving them the function of a molar tooth. These reinforce the proposals of herbivory for sphagesaurids.

\section{Acknowledgments}

We thank Deverson da Silva (Pepi) for the illustration of Caipirasuchus. Also, special thanks are due to the Editor-in-Chief, Eduardo A. M. Koutsoukos, and the reviewers for their suggestions that greatly improved the manuscript. The National Council for Scientific and Technological Development (Conselho Nacional de Desenvolvimento Científico e Tecnológico - CNPq) and the Rio de Janeiro State Research Support Foundation (Fundação Carlos Chagas Filho de Amparo à Pesquisa do Estado do Rio de Janeiro FAPERJ) financially supported this study.

\section{References}

Andrade, M.B., Bertini, R.J., 2008. A new Sphagesaurus (Mesoeucrocodylia: Notosuchia) from the Upper Cretaceous of Monte Alto City (Bauru Basin, Brazil), and a revision of the Sphagesauridae. Historical Biology 20, 101-136.

Carvalho, I.S., Bertini, R.J., 1999. Mariliasuchus: um novo Crocodylomorpha (Notosuchia) do Cretáceo da Bacia Bauru, Brasil. Geologia Colombiana 24, 83-105.

Dias-Brito, D., Musacchio, E.A., Castro, J.C., Maranhão, M.S.A.S., Suarez, J.M., Rodrigues, R., 2001. Grupo Bauru: uma unidade continental do Cretáceo no Brasil - concepções baseadas em dados micropaleontológicos, isotópicos e estratigráficos. Rèvue Paléobiologie 20, 245-304.

Fernandes, L.A., Coimbra, A.M., 1996. A Bacia Bauru (Cretáceo Superior, Brasil). Anais da Academia Brasileira de Ciências 68, 195-205.

Fernandes, L.A., Coimbra, A.M., 2000. Revisão Estratigráfica da Parte Oriental da Bacia Bauru (Neocretáceo). Revista Brasileira de Geociências 30, 717-728.

Fiorelli, L.E., Leardi, J.M., Hechenleitner, E.M., Pol, D., Basilici, G., Grellet-Tinner, G., 2016. A new Late Cretaceous crocodyliform from the western margin of Gondwana (La Rioja Province, Argentina). Cretaceous Research 60, 194-209.

Iori, F.V., Carvalho, I.S., 2009. Morrinhosuchus luziae, um novo Crocodylomorpha Notosuchia da Bacia Bauru, Brasil. Revista Brasileira de Geociências 39, $717-725$.

Iori, F.V., Carvalho, I.S., 2011. Caipirasuchus paulistanus, a new sphagesaurid (Crocodylomorpha, Mesoeucrocodylia) from the Adamantina Formation (Upper Cretaceous, Turonian-Santonian), Bauru Basin, Brazil. Journal of Vertebrate Paleontology 31, 1255-1264.

Iori, F.V., Marinho, T.S., Carvalho, I.S., Arruda-Campos, A.C., 2011. Padrão dentário dos esfagessaurídeos (Crocodyliformes, Sphagesauridae). In: Carvalho, I.S., Srivastava, N.K., Strohschoen Jr., O., Lana, C.C. (Eds.), Paleontologia: Cenários da Vida (4). Editora Interciência, pp. 585-594.

Iori, F.V., Marinho, T.S., Carvalho, I.S., Arruda-Campos, A.C. 2013. Taxonomic reappraisal of the sphagesaurid crocodyliform Sphagesaurus montealtensis from the Late Cretaceous Adamantina Formation of São Paulo state, Brazil. Zootaxa 3686 (2), 183-200.

Kellner, A.W.A., Campos, D.A., Riff, D., Andrade, M.B., 2011a. A new crocodylomorph (Sphagesauridae, Notosuchia) with horn-like tubercles from Brazil. Zoological Journal of the Linnean Society 163, S57-S65.

Kellner, A.W.A., Figueiredo, R.G., Azevedo, S.A.K., Campos, D.A., 2011b. A new cretaceous notosuchian (Mesoeucrocodylia) with bizarre dentition from Brazil. Zoological Journal of the Linnean Society 163, S115.

Kuhn, O., 1968. Die Vorzeitlichen Krokodile. Verlag Oeben, Krailing, München, 124 p.

Lecuona, A., Pol, D., 2008. Tooth morphology of Notosuchus terrestris (Notosuchia: Mesoeucrocodylia): new evidence and implications. Comptes Rendus Palevol. https://doi.org/10.1016/j.crpv.2008.07.001.

Marinho, T.S., Carvalho, I.S., 2009. An armadillo-like sphagesaurid crocodylifom from the Late Cretaceous of Brazil. Journal of South American Earth Sciences 27, 36-41.

Menegazzo, M.C., Catuneanu, O., Chang, H.K., 2016. The South American retroarc foreland system: the development of the Bauru Basin in the back-bulge province. Marine and Petroleum Geology 73, 131-156.

Nobre, P.H., Carvalho, I.S., 2006. Adamantinasuchus navae: a new Gondwanan Crocodylomorpha (Mesoeucrocodylia) from the Late Cretaceous of Brazil. Gondwana Research 10, 370-378.

Novas, F.E., Pais, D.F., Pol, D., Carvalho, I.S., Scanferla, A., Mones, A., Riglos, M.S., 2009. Bizarre notosuchian crocodyliform with associated eggs from the upper Cretaceous of Bolivia. Journal of Vertebrate Paleontology 29, 1-5.

Ösi, A., 2013. The evolution of jaw mechanism and dental function in heterodont crocodyliforms. Historical Biology: An International Journal of Paleobiology. https://doi.org/10.1080/08912963.2013.777533.

Pol, D., 2003. New remains of Sphagesaurus huenei (Crocodylomorpha: Mesoeucrocodylia) from the late Cretaceous of Brazil. Journal of Vertebrate Paleontology 23, 817-831.

Pol, D., Nascimento, P.M., Carvalho, A.B., Riccomini, C., Pires-Domingues, R.A., et al., 2014. A new Notosuchian from the late Cretaceous of Brazil and the phylogeny of advanced Notosuchians. PLoS One 9 (4), e93105.

Price, L.I., 1950. On a new Crocodilia, Sphagesaurus from the Cretaceous of State of São Paulo, Brazil. Anais da Academia Brasileira de Ciências 22, 77-83.

Zaher, H., Pol, D., Carvalho, A.B., Riccomini, C., Campos, D., Nava, W., 2006. Redescription of the cranial morphology of Mariliasuchus amarali, and its phylogenetic affinities (Crocodyliformes, Notosuchia). American Museum Novitates $3512,1-40$ 